\title{
Retail Consolidation And The Price Elasticity Of Demand For Books
}

Thomas J. Webster (E-mail: twebster@pace.edu), Pace University

\begin{abstract}
This paper estimates a translogarithmic utility function to derive price elasticities of demand for nine categories of books published for the period 1975 to 1996. In general, more popular categories of books, such as adult fiction and non-fiction hardcover and paperbound publications, tended on average to have higher price elasticities of demand, suggesting lower retail margins than more specialized categories, such as professional books and mail order specialty items. This study also briefly examines increased consolidation and concentration in the retail book industry. While increases in oligopsony power suggests larger publisher to retailer discounts, price elasticity estimates indicate that retail margins were generally virtually unaffected during the period considered. One possible explanation is that increases in retailer profits were at the expense of publishers, which augur further concentration in the retail book industry.
\end{abstract}

\section{Introduction}

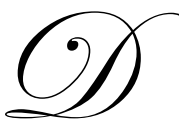

uring the last two decades there has been a dramatic consolidation of the book publishing and retail industries. Critics of mergers and acquisitions in the book publishing industry have expressed concern that the trend toward consolidation has not only stifled competition but has resulted in a decline in the variety and diversity of publications offered to the public (McDowell 1979). This concern has been exacerbated by the trend towards concentration in the retail industry, which has raised fears that growing oligopsony power has enabled large retail chains to influence publishers' production agendas. Despite the rapid increase in production, many retailers carry only the major titles of a few publishers. Even the best stocked retail outlets carry fewer than half the total number of hardbound and paperbound titles, suggesting that the reduction in the consumer choice may be the result of concentration in the retail end of the business.

Szenberg and Lee (1994) argued that fears of oligopoly power in book publishing were misplaced since barriers to entry into the industry are too low to preclude competition. The purpose this paper is to examine the possible economic consequences of consolidation in the U.S. retail book industry. In particular, this study estimates the price elasticity of demand for nine categories of U.S. book sales for the period 1975 to 1996. Estimated price elasticities were used to test the hypothesis that popular book categories are more price elastic than more specialized, less popular categories. Using the Lerner index of monopoly power, estimated price elasticities were used to determine whether retail margins were significantly affected by the trend towards consolidation in the retail book industry, and whether the growth of oligopsony power has contributed to a decline in the variety of titles offered to the public.

\section{Profile of the U.S. Book Publishing and Retailing Industries}

The U.S. book industry is comprised of production (publishing) and sales (retail), which are separate but interrelated activities. In the 1990's the publishing side of the industry consisted of approximately 20,000 firms publishing annually more than 60,000 titles spread across 26 separate categories, with total sales valued at $\$ 14$ billion.

Readers with comments or questions are encouraged to contact the author via email. 
Growth in the U.S. book publishing industry has been rapid. Between 1977 and 1997, industry sales increased about 194 percent to \$5,667 billion. There are now more than 750,000 titles listed in Bowker's Books in Print, and another 120,000 titles listed in Bowker's Paperbound Books in Print. Yet, despite the rapid increase, many retailers carry only the major titles of a few publishers. Even the best stocked retail outlets carry fewer than half the total number of hardcover and paperbound titles, which has resulted in limited access by the public.

Critics have argued that part of the reason has been the trend toward concentration of independent publishing houses into ever larger publicly held corporations. These corporations were subsequently absorbed into large media conglomerates, thereby uniting book publishing with the communications, entertainment, and motion picture industries. To make matters worse, argue critics, paperbound publishing houses were no longer separate from hardcover houses. Nearly all leading publishers of both hardcover and paperbound books are now owned by media giants.

Yet another reason for the decline in the variety of titles offered is that the rapid expansion in production has not been matched by an equivalent increase in the number of retail distribution outlets. Although there are currently around 11,000 retail outlets in the United States, which are owned by about 7,000 firms, total sales are dominated by a relatively small number of firms. The growth in the number of national chain bookstores, such as Borders, Barnes \& Noble, B. Dalton and Waldenbooks, has been accompanied with increased efficiency in the distribution of more popular titles. In 1977, the total number of retail firms employing fewer than 19 employees was 10,410 , or more than 97 percent of the total. These smaller sized firms registered sales of more than $\$ 871$ million, or about 47 percent of total sales. By 1997, the total number of retail firms employing fewer than 19 employees actually fell to 5,101 accounting for a smaller 91 percent of the total. These smaller sized firms accounted for $\$ 2,000$ million in sales, or only about 16 percent of the total.

By contrast, in 1977, the total number of retail firms employing more than 100 employees was 40 , or about 0.3 percent of the total number of retail establishments. These 40 firms accounted for total retail sales of about $\$ 625$ million, or about 34 percent of the total. By 1997, the total number of retail firms employing more than 100 employees grew to 81 firms, accounting for 1.5 percent of the total. These larger sized firms, however, registered $\$ 8,806$ million in sales, or about 72 percent to total retail sales.

Part of the reason for the consolidation in retail sales is cost. The establishment and maintenance of a retail distribution network that offers a wide selection of categories and titles requires substantial capital outlays. Small publishers unable to meet these investment requirements are forced to rely on wholesalers to identify the most appropriate retail outlets or to dispose of small printings, very often at discounted prices. In the case of large retail chains the wholesaler and retailer are one and the same. While small publishers are at a competitive disadvantage because high marketing costs represent significant barriers to entry into the retail end of the business, large publishers must also contend with the growing market power of large retailers. Computerized inventory and up-to-date sales reporting are closely watched by publishers. Large retail chains have considerable influence with publishers in evaluating the potential book sales prior to publication and their opinions are often solicited by publishers (Whiteside, 1980). In fact, the growing trend towards integration and consolidation in book publishing may be seen as a reaction to the growing market power of large retailers.

Other, more general, factors accounting for integration in the U.S. book publishing and retailing industry include the growth of non-print, mass-marketing media (commercial and cable television, radio, movies, and the Internet, for example), and trends in urbanization and sub-urbanization that have resulted in more densely populated consumer markets. Scale economies in marketing and retailing have assumed increasing importance with competition amongst retail chains competing for premium valued locations, such as shopping malls.

The trend towards concentration at the retail end of the business suggest that elements of oligopsony power have been introduced into the U.S. book industry, which would indicate that large retail chains are able to extract deep discounts from book publishers. This oligopsony power is further reflected in the fact that publishers' agenda is influenced by feedback from representatives of national bookstore chains (Szenberg and Lee, 1994). One question that suggests itself is whether publisher/retailer discounts have increased with concentration in the retail industry, and whether these discounts have been passed along to the consumer in the form of smaller retail markups. 


\section{The Lerner Index}

Bittlingmayer $(1988,1992)$ argued that book publishing is a monopolistically competitive industry and that it was possible to derive a measure of the degree of monopoly power. From the first-order condition for profit maximization it may be shown that

$$
(p ! \square c) / p=O_{p}^{-1}
$$

where $p$ is the price, $c$ is marginal cost, and $O \square_{p}$ is the price elasticity of demand.

The left-hand side of equation (1) is the familiar index of monopoly power attributable to Abba Lerner (1934), which may be used for estimating of the price elasticity of demand. Unfortunately, while $p$ is directly observable, $c$ is not, although a large fraction of the total cost of producing a title is fixed. Conversely, if the price elasticity of demand is known, then equation (1) provides a way of estimating a firms monopoly power since that the greater (smaller) the price elasticity of demand then the smaller (greater) will be the retailers' margin.

Bittlingmayer (1992) demonstrated that a modified version of equation (1) may be derived to explicitly account for promotional expenditures. Designating $v$ as the marginal cost of a unit of advertising, the familiar Lerner index may be rewritten as

$$
(p ! v ! c) / p=O_{p}^{-1}
$$

It was also shown that the elasticity of demand for books with respect to the retail margin may be written as

$$
(p ! v ! c) / v=O_{v}^{-1}
$$

The relationship between the price and advertising elasticities of demand is

$$
O \square_{p}+\square O_{v}=\square ! 1 ![c /(p ! \square v ! c)]
$$

Assuming a constant ratio of marginal cost to publisher earnings per book, $p ! v ! c$, it can be easily demonstrated that $O \square_{p}$ and $O \square_{v}$ vary directly. Equation (4) says that book sales that are responsive to promotional efforts are also responsive to price changes. The demand for titles with large price elasticities of demand are also those that are more easily influenced by promotional efforts, which partly explains why novels are more actively promoted than, say, research monographs. Equation (4) also suggests that, contrary to casual observation, the purpose of advertising is not to make the demand for books less price elastic.

Comprehensive and consistent price, cost, and sales data for the U.S. book publishing industry are not generally available. For this reason, it is not possible to directly estimate retail margins. Instead, estimates of retail margins for nine categories of books were obtained by first obtaining the price elasticities of demand for nine categories of books from an estimated transcendental logarithmic (translogarithmic or translog) indirect utility specification, and then applying equation (1) to obtain retail margins. Estimated retail margins were then examined to determined possible trends in consumer discounts over the period from 1975 to 1996 . Unfortunately, since it is not possible to obtain actual data on retail margins, these estimates are not subject to verification. Nevertheless, the trends in estimated price elasticities are instructive, and confirmation of these results suggests a possible further area of inquiry.

\section{Econometric Estimates}

Table 1 represents the final non-linear ITSUR parameter estimates, where the independent variables with the suffix "P" designate book category prices and the dependent variables prefixed with an "S" designate total retail value shares. Table 1 also includes $t$-statistics (in parentheses) and the adjusted coefficients of determination (Adj. $R^{2}$ ). Table 2 summarizes the estimated Allen-Uzawa price elasticities of demand and associated retail markups in the period 1975 to 1996. Finally, Table 3 summarizes the estimated associated retail markups in each category based on equation (1). 
Table 1: Nonlinear ITSUR Parameter Estimates of the Indirect Utility Function

\begin{tabular}{|c|c|c|c|c|c|c|c|c|c|}
\hline Parameter & SADTRD & SJVTRD & SRELG & SPROF & SBKCLB & SELHI & SCOLL & SMAILS & SPPRBD \\
\hline \multirow[t]{2}{*}{ Constant } & $0.410 \%$ & $0.050^{*}$ & 0.015 & $0.113^{*}$ & $-0.063 \dagger$ & $0.141 \dagger$ & 0.318 & 0.103 & -0.977 \\
\hline & $(7.39)$ & $(1.34)$ & $(0.26)$ & (1.63) & $(-2.30)$ & (2.03) & $(4.29) \$$ & $(2.12) \dagger$ & -- \\
\hline \multirow[t]{2}{*}{ ADTRDP } & 0.054 & $0.761 \ddagger$ & 0.006 & $-0.085 \$$ & 0.004 & -0.014 & $-0.044 \dagger$ & $-0.073 \dagger$ & $0.089 \ddagger$ \\
\hline & (1.16) & $(5.43)^{\circ}$ & $(0.25)$ & $(-4.00)$ & $(0.26)$ & $(-0.57)$ & $(-1.98)$ & $(-3.56)^{\circ}$ & $(3.28)^{\circ}$ \\
\hline \multirow[t]{2}{*}{ JVTRDP } & $0.761 \%$ & $0.032 \dagger$ & -0.008 & $-0.057 \ddagger$ & $-0.010^{*}$ & 0.005 & -0.009 & 0.008 & 0.008 \\
\hline & $(5.43)$ & $(2.10)$ & $(-0.66)$ & $(-4.05)$ & $(-1.46)$ & $(0.30)$ & $(-0.64)$ & $(0.62)$ & $(0.45)$ \\
\hline \multirow[t]{2}{*}{ RELGP } & 0.006 & -0.008 & 0.005 & -0.016 & -0.002 & -0.003 & $0.0421 *$ & 0.023 & $-0.034 *$ \\
\hline & $(0.25)$ & $(-0.66)$ & $(0.16)$ & $(-0.78)$ & $(-0.27)$ & $(-0.13)$ & (1.64) & (1.33) & $(-1.39)$ \\
\hline \multirow[t]{2}{*}{ PROFP } & $-0.085 t$ & $-0.057 \ddagger$ & -0.016 & $0.094 \$$ & $0.062 \ddagger$ & 0.027 & $-0.036^{*}$ & -0.008 & 0.032 \\
\hline & $(-4.00)^{\circ}$ & $(-4.05)^{\circ}$ & $(-0.78)$ & $(3.27)^{\circ}$ & $(6.75)^{\top}$ & (1.11) & $(-1.48)$ & $(-0.43)$ & (1.28) \\
\hline \multirow[t]{2}{*}{ BKCLBP } & 0.004 & $-0.010^{*}$ & -0.002 & $0.062 \ddagger$ & -0.003 & $-0.034 \ddagger$ & $0.030 \ddagger$ & $-0.019 \dagger$ & $-0.035 \ddagger$ \\
\hline & $(0.26)$ & $(-1.46)$ & $(-0.27)$ & $(6.75)^{\circ}$ & $(-0.57)$ & $(-3.19)^{\circ}$ & $(2.70)^{\circ}$ & $(-2.30)$ & $(-3.29)^{\circ}$ \\
\hline \multirow[t]{2}{*}{ ELHIP } & -0.014 & 0.005 & -0.003 & 0.027 & $-0.034 \ddagger$ & 0.012 & $-0.046^{*}$ & $0.033 *$ & 0.016 \\
\hline & $(-0.57)$ & $(0.30)$ & $(-0.13)$ & (1.11) & $(-3.19)$ & $(0.34)$ & $(-1.70)$ & $(1.53)$ & $(0.52)$ \\
\hline \multirow[t]{2}{*}{ COLLP } & $-0.044 \dagger$ & -0.009 & $0.042 *$ & $-0.036^{*}$ & $0.030 \ddagger$ & $-0.046^{*}$ & -0.038 & 0.003 & $0.064 \dagger$ \\
\hline & $(-1.98)$ & $(-0.64)$ & (1.64) & $(-1.48)$ & $(2.70)$ & $(-1.70)$ & $(-1.07)$ & $(0.12)$ & $(2.29)$ \\
\hline \multirow[t]{2}{*}{ MAILP } & $-0.073 \ddagger$ & 0.008 & 0.023 & -0.008 & $-0.019 \dagger$ & $0.033^{*}$ & 0.003 & $0.038^{*}$ & -0.025 \\
\hline & $(-3.56)$ & $(0.62)$ & (1.33) & $(-0.43)$ & $(-2.30)$ & $(1.53)$ & $(0.12)$ & $(1.66)$ & $(-1.07)$ \\
\hline \multirow[t]{2}{*}{ PPRBD } & $0.089 \$$ & 0.008 & $-0.034 *$ & 0.032 & $-0.035 \ddagger$ & 0.016 & $0.064 \dagger$ & -0.025 & -0.115 \\
\hline & $(3.28)^{\circ}$ & $(0.45)$ & $(-1.39)$ & $(1.28)$ & $(-3.29)^{\circ}$ & $(0.52)$ & $(2.29)$ & $(-1.07)$ & -- \\
\hline Adj. $R^{2}$ & 0.67 & 0.95 & 0.41 & 0.88 & 0.78 & 0.63 & 0.66 & 0.83 & -- \\
\hline
\end{tabular}

Notes: “*” statistically significant at the 90 percent confidence level; " $\dagger ”$ statistically significant at the 95 percent confidence level for a one-tail test; " $\$$ " statistically significant at the 99 percent confidence level for a one-tailed test.

The data presented in Tables 1 and 2 suggest that the demand for books during the period examined was generally price inelastic. The exceptions were college texts (COLL), paperbound books (PPRD), and book club selections (BKCLB), where the average price elasticities of demand for the period were $-1.18,-1.94$, and -1.03 , respectively. The price elasticity of demand for the remaining categories ranged from -0.25 for professional (PROF) and mail order specialty items (MAIL) to -0.86 for religious (RELG) titles. Although Bittlingmayer found that for the German book publishing industry the price elasticities of demand ranged between -1.5 and -3.0 , these differences were probably the result of differences in the retail distributions systems.

The results presented in Table 2 appear to support Bittlingmayer's findings that more popular categories of books tended to be more price elastic than titles with smaller printings. During the period 1975 to 1996 the most price elastic category was paperbound titles (-1.94) also had the highest average annual unit sales (464 million). The least elastic category (-0.25) was professional books, which had the smallest average annual unit sales (113 million). One notable exception was the demand for college texts, which was the second most price-elastic category (-1.18) despite low average annual unit sales (119 million). One possible explanation for this anomaly is the existence of a robust used-book market for college texts. Another possible explanation is the increasing use of the internet by college students when ordering texts.

By contrast, elementary and high-school texts (ELHI) were price inelastic (-0.79) than college texts and had significantly higher average per unit sales (227 million). This should not be surprising since the primary consumer of primary and secondary school texts are public boards of education. These text books are the property of the local school district and are made available to the student for temporary use. Since these purchases are typically funded by local taxes, the decision as to which texts to adopt are less price sensitive than would be the case if parents were permitted to comparison shop for assigned texts, as is the case with college texts. Thus, unlike college text books, since the end use does not own the text book, there is no robust used-book or internet market for elementary and high-school texts.

Equation (1) suggests that the lower the price elasticity of demand the higher the estimated retail markup. The elasticity estimates summarized in Table 2 suggests that estimated retail margins, which are summarized in Table 3, may be higher for more specialized categories, such as professional books and mail order specialty items, than for more popular categories like paperbound and adult fiction and non-fiction titles (ADTRD). The estimated retail 
margin for paperbound books was only 52 percent of the retail price, compared with a 400 percent markup for professional and mail order books. While these estimates require confirmation, they should not come as a surprise to anyone who is familiar with the respective prices charged by college books, which are often operated by major retail outlets, such as Barnes \& Noble.

Table 2: Estimated Allen-Uzawa Price Elasticities of Demand, Retail Margins, and Unit Sales*

\begin{tabular}{|c|c|c|c|c|c|c|}
\hline & 1975 & 1980 & 1985 & 1990 & 1996 & Average 1975-1996 \\
\hline$\square_{A D T R D}$ & -0.53 & -0.54 & -0.54 & -0.53 & -0.53 & -0.53 \\
\hline$\square$ JVRD & -0.20 & -0.21 & -0.44 & -0.55 & -0.58 & -0.42 \\
\hline$\square_{R E L G}$ & -0.86 & -0.87 & -0.86 & -0.87 & -0.87 & -0.86 \\
\hline$\square_{\text {PROF }}$ & -0.11 & -0.29 & -0.28 & -0.26 & -0.28 & -0.25 \\
\hline$\square_{B K C L B}$ & -0.97 & -1.01 & -1.03 & -1.06 & -1.04 & -1.03 \\
\hline$\square_{E L H I}$ & -0.78 & -0.79 & -0.78 & -0.79 & -0.79 & -0.79 \\
\hline$\square$ COLL & -1.18 & -1.14 & -1.16 & -1.20 & -1.22 & -1.18 \\
\hline$\square_{M A I L}$ & -0.44 & -0.37 & -0.26 & -0.13 & -0.09 & -0.25 \\
\hline$\square$ PPRBND & -1.60 & -1.93 & -1.98 & -2.12 & -2.13 & -1.94 \\
\hline
\end{tabular}

The results presented in Table 2 also support Bittlingmayer's observation that book sales that are the responsive to promotional and advertising efforts also have higher price elasticities of demand. Publishers routinely expend large sum to promote popular, mass-appeal titles, especially for such proven authors as Tom Clancy and Stephen King, and spend little to nothing promoting the works of, say, Thomas Sowell or Hal Varian.

The results presented in Table 2 also suggest that in spite of the trend towards increased retail conglomeration and concentration, retail margins were virtually unchanged for most categories of publications during the period studied. This is significant since greater retail consolidation suggests an increased ability by retailers to extract larger discounts from publishers. In determining whether consolidation in the retail industry has been beneficial to the public, it is important to question whether these potential discounts have been passed along to the consumer. In general, the data presented in Table 3 suggest that this was not the case. The most notable exception was the juvenile book (JUVTRD) category where estimated retail margins fell steadily from about 500 percent in 1975 to around 172 percent in 1996, which reflects growing the significant increase in per unit sales and the associated higher price elasticities of demand.

One possible explanation for why predicted discounts would not be passed along to consumers is that increased oligopsony power may have been offset by the parallel increase in oligopoly power in the publishing industry. Szenberg and Lee (1994) have argued, however, that despite the trend towards concentration in the book publishing industry that estimates of the minimum optimal production scale were too small to obstruct entry of new firms into the industry. This suggests that one of the most important requirements for a workable competitive industry is satisfied. An alternative interpretation is that increased wholesaler/retailer profits have come at the expense of publishers. 
Table 3: Estimated Retail Margins, and Unit Sales*

\begin{tabular}{|c|c|c|c|c|c|c|c|}
\hline & & 1975 & 1980 & 1985 & 1990 & 1996 & Average 1975-1996 \\
\hline \multirow{2}{*}{$A D T R D$} & Margin & 189 & 185 & 185 & 189 & 189 & 189 \\
\hline & Unit Sales & 182 & 369 & 360 & 403 & 440 & 363 \\
\hline$J V R D$ & Unit Sales & 90 & 118 & 193 & 301 & 379 & 214 \\
\hline \multirow[t]{2}{*}{$R E L G$} & Margin & 116 & 115 & 116 & 115 & 115 & 116 \\
\hline & Unit Sales & 96 & 152 & 134 & 130 & 155 & 137 \\
\hline \multirow[t]{2}{*}{ BKCLB } & Margin & 104 & 99 & 97 & 94 & 96 & 97 \\
\hline & Unit Sales & 195 & 127 & 130 & 108 & 132 & 136 \\
\hline \multirow[t]{2}{*}{ ELHI } & Margin & 128 & 127 & 128 & 127 & 127 & 127 \\
\hline & Unit Sales & 257 & 217 & 234 & 209 & 245 & 227 \\
\hline COLL & Margin & 85 & 88 & 86 & 83 & 82 & 85 \\
\hline \multirow[t]{2}{*}{ PPRBND } & Margin & 63 & 52 & 51 & 47 & 47 & 52 \\
\hline & Unit Sales & 491 & 495 & 382 & 433 & 458 & 464 \\
\hline
\end{tabular}

* Unit sales in millions.

Concern has been voiced in many quarters that the merger and acquisition trend in the book publishing industry has compromised the publishing industry's responsibility as gatekeeper of the nation's culture in favor of profits. The Author's Guild, which represents the interests of nearly 5,000 professional writers, has argued that concentration in the book publishing had gone "beyond the limits of fair competition as defined in the Clayton AntiTrust Act and is contrary to the uninhibited marketplace of ideas guaranteed by the First Amendment" (McDowell, 1979). Where formerly commercially successful books helped pay for high quality titles of limited appeal, critics argue that many of today's publishers seek only books with a mass audience.

While the Authors Guild may have reason to be concerned that variety and diversity of publications offered to the public may have fallen victim to the corporation's single-minded quest for profits, the results presented in Tables 2 and 3 suggest an alternative explanation. The decline in title offerings may, in fact, be the result of a decline in retail competition rather than increased concentration in book publishing. If correct, this interpretation would suggest that growing retail profit margins presage further consolidation, and an increased ability to influence publishers production agendas. On the other hand, increased competition in the form of internet vendors may form an effective bulwark against such an occurrence.

\section{Summary}

This study estimated the price elasticity of demand for nine categories of books for the U.S. publishing industry for 1975-1996 period. The study found that, in general, the price elasticity of demand for more popular categories of books tended to have a higher price elasticity of demand than less popular categories. Titles with higher price elasticities of demand are expected to have lower retail markup than titles with lower price elasticities of demand. The study revealed that during the period examined, paperbound titles had highest unit sales and the lowest retail markups, while professional books and mail-order specialty items had the lowest unit sales and the highest retail markups.

This study also examined the trend in retailer margins in light of increased consolidation and concentration at the retail end of the publishing business. While oligopsony theory suggests that increased concentration should result in larger publisher to retailer discounts, these discounts, if realized, were not passed along to the consumer in the form of lower retail markups. One possible explanation is that the increase retailer profits were at the expense of publishers, which augur further concentration in the retail book industry. 


\section{References}

1. Bittlingmayer, G. "Resale price maintenance in the book trade with an application to Germany," Journal of Institutional and Theoretical Economics, 144(4) (1988), 789-812.

2. Bittlingmayer, G. "The elasticity of demand for books, retail price maintenance and the Lerner index," Journal of Institutional and Theoretical Economics, 148(4) (1992), 588-606.

3. Christensen, L.R., D.W. Jorgenson, and L.J. Lau. "Conjugate duality and the transcendental logarithmic function," Econometrica, 39 (1971), 255-256.

4. _. "Transcendental logarithmic utility function," American Economic Review, 65 (1975), 367-383.

5. Lerner, A. "The concept of monopoly and the measurement of monopoly power," Review of Economic Studies, 1(3) (1934), 157-175.

6. McDowell, E. "Statement on the continuing trend to concentration of power in the book publishing industry," Authors Guild Bulletin (1979).

7. Shephard, R.W. Cost and production functions (Princeton, NJ: Princeton University Press, 1953).

8. ‥ The theory of cost and production functions (Princeton, NJ: Princeton University Press, 1970).

9. $\quad$ Szenberg, M. and E. Y. Lee. "The structure of the American book publishing industry," Journal of Cultural Economics, 18 (1994), 313-322.

10. Whiteside, T. (1980), "The blockbuster complex-I", The New Yorker, September 29, p.95.

11. _. "The blockbuster complex-II", The New Yorker, October 6, 1980, p. 70.

12. Zellner, A. "An efficient method for estimating seemingly unrelated regressions and tests for aggregation bias," Journal of the American Statistical Association, 57 (1962), 348-368. 
Notes 